\title{
Epidural spinal electrical stimulation in severe angina pectoris
}

\author{
CLAS MANNHEIMER, * LARS-ERIK AUGUSTINSSON, $\dagger$ \\ CARL-AXEL CARLSSON, $\dagger$ KARIN MANHEM, * CLAES WILHELMSSON *

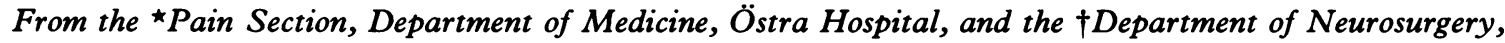 \\ Sahlgrenska Hospital, Gothenburg, Sweden
}

SUMMARY The short term effects of epidural spinal electrical stimulation were studied in 10 patients with angina pectoris of New York Heart Association functional class III or IV. The antianginal pharmacological treatment given at entry to the study was regarded as optimal and was not changed during the study. The effects of epidural spinal electrical stimulation were measured by repeated bicycle ergometer tests. Treatment with epidural spinal electrical stimulation increased the patients' working capacity, decreased ST segment depression, increased time to angina, and reduced the recovery time. The observed effects did not seem to be correlated with any changes in myocardial oxygen demand during epidural spinal electrical stimulation and were additional to the benefits of the pharmacological treatment.

Patients with severe angina pectoris treated with transcutaneous electrical nerve stimulation had a reduction of chest pain, an increase in working capacity, and a reduction in ST segment depression. ${ }^{1}$ Some patients had skin irritation of different kinds and in some the stimulation equipment restricted physical activity. These patients were offered the opportunity to test epidural spinal electrical stimulation by a fully implanted system. Epidural spinal electrical stimulation has been used successfully to treat chronic intractable pain and peripheral vascular disease. ${ }^{2}$

We have assessed the clinical usefulness of epidural spinal electrical stimulation in the treatment of patients with severe angina pectoris.

\section{Patients and methods}

\section{PATIENTS}

Ten patients (two women and eight men, aged 51-74 years) were selected from the medical outpatient clinic at Östra Hospital, Gothenburg. Table 1 summarises the patient characteristics. All patients had severe angina pectoris (New York Heart Association functional class III or IV). No patients had

Requests for reprints to Dr Clas Mannheimer, Department of Medicine, Östra Hospital, S-416 85 Gothenburg, Sweden.

Accepted for publication 8 September 1987 obstructive or restrictive pulmonary disease, intermittent claudication, valve disease, or had had a myocardial infarction within the last six months. All patients had been considered for bypass surgery: four patients had had the operation, two were current candidates for surgery, and four patients were not considered suitable for operation. All patients except two had had a myocardial infarction. The antianginal medication that they were taking at entry to the study was regarded as optimal and treatment was not changed during the study. The patients were told not to smoke or take short acting nitrates for at least two hours before the exercise tests. All patients had been treated with transcutaneous electrical nerve stimulation which had to be stopped because of skin irritation (in seven patients) and/or because the treatment markedly restricted the patient's normally high physical activity (six patients).

The patients were fully informed about the study before entering it. All patients gave their verbal consent to inclusion in the trial. The trial was approved by the University of Gothenburg ethical review committee.

\section{SURGICAL TECHNIQUE AND STIMULATION} EQUIPMENT

The stimulation equipment was implanted in the operating theatre by a sterile technique. The patient was placed on an $x$ ray translucent table. The oper- 
Table 1 Patient characteristics

\begin{tabular}{|c|c|c|c|c|c|c|c|c|c|}
\hline Case No & Age (yr) & Sex & $\begin{array}{l}\text { Duration of } \\
\text { angina (yr) }\end{array}$ & $\begin{array}{l}\text { Previous } \\
\text { infarction }\end{array}$ & $\begin{array}{l}\text { Relative heart } \\
\text { volume ( } \mathrm{ml} / \mathrm{m}^{2} \\
\text { body surface) }\end{array}$ & $\begin{array}{l}\text { Lactate } \\
\text { production } \\
\text { during atrial } \\
\text { pacing }\end{array}$ & $\begin{array}{l}\text { Antianginal } \\
\text { treatment }\end{array}$ & $\begin{array}{l}\text { Other } \\
\text { treatment }\end{array}$ & $\begin{array}{l}\text { Bypass } \\
\text { surgery }\end{array}$ \\
\hline 1 & 72 & $\mathbf{M}$ & 10 & + & 850 & + & SAN, LAN, BB & $\begin{array}{l}\text { Digitalis, : } \\
\text { diuretics }\end{array}$ & Not suitable \\
\hline 2 & 61 & $\mathbf{M}$ & 9 & + & 400 & + & $\underset{\text { CA }}{\text { SAN, LAN, BB, }}$ & $\begin{array}{l}\text { Digitalis, } \\
\text { diuretics }\end{array}$ & Yes \\
\hline 3 & 51 & $\mathbf{F}$ & 2 & - & 370 & + & SAN, LAN, BB & 一 & $\begin{array}{l}\text { Current } \\
\text { candidate }\end{array}$ \\
\hline 4 & 60 & $\mathbf{M}$ & 14 & + & 420 & + & SAN, LAN, BB & $\begin{array}{l}\text { Digitalis, } \\
\text { diuretics }\end{array}$ & Yes \\
\hline 5 & 72 & $\mathbf{M}$ & 8 & + & 430 & + & $\underset{\text { CA }}{\text { SAN, LAN, BB, }}$ & - & Not suitable \\
\hline 6 & 72 & $\mathbf{M}$ & 10 & + & 720 & Not performed & SAN, LAN, BB & $\begin{array}{l}\text { Digitalis, } \\
\text { diuretics }\end{array}$ & Not suitable \\
\hline $\begin{array}{l}7 \\
8 \\
9\end{array}$ & $\begin{array}{l}66 \\
64 \\
61\end{array}$ & $\begin{array}{l}\mathbf{M} \\
\mathbf{M} \\
\mathbf{F}\end{array}$ & $\begin{array}{r}11 \\
9 \\
7\end{array}$ & $\begin{array}{l}+ \\
+ \\
-\end{array}$ & $\begin{array}{l}420 \\
410 \\
390\end{array}$ & $\begin{array}{l}+ \\
\text { Not performed } \\
\text { Not performed }\end{array}$ & $\begin{array}{l}\text { SAN, LAN, BB } \\
\text { SAN, LAN } \\
\text { SAN, LAN, BB }\end{array}$ & $\bar{z}$ & $\begin{array}{l}\text { Yes } \\
\text { Yes } \\
\text { Current } \\
\text { candidate }\end{array}$ \\
\hline 10 & 63 & $\mathbf{M}$ & 14 & + & 480 & Not perfomed & $\begin{array}{l}\text { SAN, LAN, BB, } \\
\text { CA }\end{array}$ & - & Not suitable \\
\hline
\end{tabular}

SAN, short acting nitrates; LAN, long acting nitrates; BB, $\beta$ blockers; $C A$, calcium antagonists.

ation was performed under local anaesthesia to allow the patient to answer questions from the surgeon during the preoperative test stimulation. The electrode was positioned so that the patient felt a prickling sensation in the region of anginal pain. The ideal position is when the stimulation produces a prickling sensation starting in the precordial area and spreading into the arms as the strength of the current is increased.

The skin incision was made in the midline in the midthoracic region. The epidural space was punctured at the level of T6. A Touhy-type needle was advanced in the midline through the interspaces into the epidural space, which was identified by the loss of resistance method. The stylet of the electrode was bent $20^{\circ} 10 \mathrm{~mm}$ from the distal end to make it easier to manipulate the electrode in the epidural space. The electrode tip was placed in the midline or a few millimetres to the left at the level of T1-T2. The distal end of the intraspinal electrode is sigma shaped to prevent migration. The electrode was firmly sutured to the fascia for the same reason. Unipolar stimulation was used. The pulse generator was placed in a subcutaneous pouch below the left costal arch. An extension lead was tunnelled subcutaneously to the midline incision and connected to the electrode. The pulse generator was telemetrically programmed. We used a commercially available electrical device (Mectronic., Minneapolis, $M N$, USA). The pulse width was $210 \mu \mathrm{s}$, frequency $85 \mathrm{~Hz}$, and an appropriate amplitude was used to produce for comfortable paraesthesia (usually $3-6 \mathrm{~V}$ ). The pulse generator is turned on or off by a quick touch with an external magnet on the skin over the pulse generator.
DESIGN OF THE STUDY AND EFFECT

\section{EVALUATION}

The study consisted of three parts:

$A$ run in period (one to two weeks) to standardise the exercise test for each patient and to confirm that the patients were suitable candidates. Three or four tests were performed.

$A$ treatment period (two weeks) when the individually standardised exercise tests were performed. Each patient performed four tests with stimulation and four without, in alternate order.

$A$ post-treatment period (two days) to measure the patient's working capacity after the study.

After the run in period, the stimulator was implanted (see below) and the patients then had a one week postoperative convalescence before the treatment period started.

The following variables were used to assess the effect of epidural spinal electrical stimulation: $(a)$ Pulse rate, blood pressure, and the product pulse rate $\times$ blood pressure before, during, and after exercise; (b) maximal total work during exercise; (c) estimated anginal pain and dyspnoea score during and after exercise; (d) ST changes during and after exercise; $(e)$ the time until the occurrence of angina during exercise tests (time to angina) and recovery time after maximal total work until the pain disappeared; $(f)$ the reason for stopping the exercise test. The electrocardiographic characteristics of the patients were analysed with a Marquette CASE 1 electrocardiogram apparatus (Marquette Electronics, Milwaukee, WI, USA), which was used for continuous monitoring throughout the exercise session. This device eliminates noise and baseline variations in the electrocardiogram and can measure ST segment 
displacement with an accuracy of $0.1 \mathrm{~mm}(0.01 \mathrm{mV})$, which is five times better than can be done by ocular assessment. The systolic blood pressure was measured by a sphygmomanometer.

Exercise tests were always performed both in the morning and in the afternoon. During the treatment period, the order of the daily runs with and without stimulation was alternated randomly. An electrically braked bicycle ergometer (Siemens-Elema) was used and the test was always performed in the same room, at the same temperature, and at the same time of the day. The workload was increased every minute. An increase of 5 or $10 \mathrm{~W}$ was used for each patient. The starting load was chosen so that the patient reached his maximum total work after 5-9 minutes. The total work was calculated as the sum of the load-time products for each minute. During the exercise tésts with stimulation, the stimulator was switched off for the last 15 seconds of each minute to avoid the stimulator interfering with the electrocardiogram.

Chest pain and dyspnoea were rated according to a common scale ranging from 0 to 5 : where 0 represents no discomfort, 3 discomfort equivalent to that which normally stopped the patient's activities, 4 severe, and 5 maximum discomfort. To reach maximum discomfort, the patients were urged to continue their exercise to levels producing either pain or dyspnoea of grade 4 or 5 . When the maximal workload was reached, the degree of anginal pain and dyspnoea was recorded each minute until angina score was 0 (recovery time).

To evaluate the statistical significance of the effects of epidural spinal electrical stimulation, the data were grouped in three ways: $(a)$ Run in values were compared with those recorded without epidural spinal electrical stimulation in the treatment period, (b) values recorded without epidural spinal electrical stimulation were compared with those during epi- dural spinal electrical stimulation; and (c) run in values were compared with post-treatment values.

Data were compared by Fisher's test for paired comparisons. ${ }^{3}$ The test is non-parametric. Twosided tests were used.

\section{Results}

No complications or adverse effects were seen during the exercise tests and all 10 patients completed the study. In one patient, the tip of the electrode was initially placed too high and in another patient the electrode migrated. These two patients were easily reoperated on and electrical stimulation was later successful.

Table 2 shows the heart rate, mean systolic blood pressure, and product of heart rate and blood pressure at maximal work, and table 3 shows the same variables at maximal comparable work. Maximal comparable work is defined as the lowest individual maximal work that a patient reached in the series of tests and thus represents the highest workload that can be used for a comparison study. There were no differences between the group treated with epidural spinal electrical stimulation and the untreated groups for data in table 4.

Time to angina was shorter during the posttreatment period than during the run in $(p<0.05$, table 4). No further statistically significant effects were seen when run in data were compared either with data recorded without epidural spinal electrical stimulation or with post-treatment data.

The following differences between values on and off epidural spinal electrical stimulation were statistically significant: an increase in maximal work capacity (p<0.01, table 5), a decrease in the magnitude of ST segment depression at the highest comparable workload ( $p<0.01$, table 6$)$, an increase in

Table 2 Mean systolic blood pressure (SBP), mean heart rate ( $H R$ ), and mean product of systolic blood pressure and heart rate at maximal work

\begin{tabular}{|c|c|c|c|c|c|c|c|c|c|c|c|c|}
\hline \multirow[b]{3}{*}{ Case No } & \multirow{2}{*}{\multicolumn{3}{|c|}{ Run in }} & \multicolumn{6}{|c|}{ Treatment period } & & & \\
\hline & & & & \multicolumn{3}{|c|}{ Without ESES } & \multicolumn{3}{|c|}{ With ESES } & \multicolumn{3}{|c|}{ Post-treatment } \\
\hline & $H R$ & $S B P$ & $H R \times S B P$ & $H R$ & $S B P$ & $H R \times S B P$ & $H R$ & $S B P$ & $H R \times S B P$ & $H R$ & $S B P$ & $H R \times S B P$ \\
\hline $\begin{array}{r}1 \\
2 \\
3 \\
4 \\
5 \\
6 \\
7 \\
8 \\
9 \\
10\end{array}$ & $\begin{array}{r}106 \\
67 \\
128 \\
97 \\
85 \\
126 \\
97 \\
134 \\
124 \\
105\end{array}$ & $\begin{array}{l}130 \\
127 \\
150 \\
155 \\
165 \\
220 \\
148 \\
207 \\
217 \\
170\end{array}$ & $\begin{array}{r}13750 \\
8537 \\
19197 \\
15078 \\
14082 \\
27720 \\
14385 \\
27707 \\
26643 \\
17793\end{array}$ & $\begin{array}{r}113 \\
77 \\
125 \\
94 \\
95 \\
115 \\
98 \\
132 \\
114 \\
106\end{array}$ & $\begin{array}{l}123 \\
120 \\
158 \\
169 \\
177 \\
224 \\
146 \\
201 \\
223 \\
184\end{array}$ & $\begin{array}{r}13600 \\
9230 \\
19793 \\
15885 \\
16683 \\
25575 \\
14244 \\
26631 \\
25380 \\
19501\end{array}$ & $\begin{array}{r}105 \\
79 \\
150 \\
102 \\
89 \\
118 \\
109 \\
141 \\
124 \\
109\end{array}$ & $\begin{array}{l}117 \\
137 \\
176 \\
155 \\
167 \\
224 \\
143 \\
194 \\
203 \\
175\end{array}$ & $\begin{array}{l}12243 \\
10817 \\
25925 \\
15739 \\
14781 \\
25908 \\
15565 \\
27225 \\
25196 \\
18820\end{array}$ & $\begin{array}{r}103 \\
73 \\
132 \\
90 \\
86 \\
118 \\
96 \\
139 \\
109 \\
103\end{array}$ & $\begin{array}{l}121 \\
135 \\
165 \\
178 \\
165 \\
120 \\
145 \\
195 \\
210 \\
190\end{array}$ & $\begin{array}{r}12643 \\
9750 \\
21695 \\
15968 \\
14190 \\
25960 \\
13950 \\
27105 \\
22785 \\
19750\end{array}$ \\
\hline $\begin{array}{l}\text { Mean } \\
\text { SD }\end{array}$ & $\begin{array}{r}107 \\
21\end{array}$ & $\begin{array}{r}169 \\
34\end{array}$ & $\begin{array}{r}18469 \\
6699\end{array}$ & $\begin{array}{r}107 \\
16\end{array}$ & $\begin{array}{r}173 \\
37\end{array}$ & $\begin{array}{r}18652 \\
5813\end{array}$ & $\begin{array}{r}113 \\
22\end{array}$ & $\begin{array}{r}169 \\
33\end{array}$ & $\begin{array}{r}19221 \\
6273\end{array}$ & $\begin{array}{r}105 \\
21\end{array}$ & $\begin{array}{r}172 \\
32\end{array}$ & $\begin{array}{r}18361 \\
5923\end{array}$ \\
\hline
\end{tabular}

ESES, epidural spinal electrical stimulation. 
Table 3 Mean systolic blood pressure (SBP), mean heart rate (HR), and mean product of systolic blood pressure and heart rate at maximal comparable work

\begin{tabular}{|c|c|c|c|c|c|c|c|c|c|c|c|c|}
\hline \multirow[b]{3}{*}{ Case No } & \multirow{2}{*}{\multicolumn{3}{|c|}{ Run in }} & \multicolumn{6}{|c|}{ Treatment period } & & & \\
\hline & & & & \multicolumn{3}{|c|}{ Without ESES } & \multicolumn{3}{|c|}{ With ESES } & \multicolumn{3}{|c|}{ Post-treatment } \\
\hline & $H R$ & $S B P$ & $H R \times S B P$ & $\overline{H R}$ & $S B P$ & $H R \times S B P$ & $\overline{H R}$ & $S B P$ & $H R \times S B P$ & $\overline{H R}$ & $S B P$ & $H R \times S B P$ \\
\hline $\begin{array}{r}1 \\
2 \\
3 \\
4 \\
5 \\
6 \\
7 \\
8 \\
9 \\
10\end{array}$ & $\begin{array}{r}106 \\
66 \\
122 \\
93 \\
84 \\
129 \\
90 \\
128 \\
116 \\
103\end{array}$ & $\begin{array}{l}130 \\
127 \\
145 \\
163 \\
152 \\
217 \\
145 \\
203 \\
215 \\
170\end{array}$ & $\begin{array}{r}13750 \\
8407 \\
17755 \\
15070 \\
12815 \\
27993 \\
13532 \\
25983 \\
24912 \\
17425\end{array}$ & $\begin{array}{r}110 \\
74 \\
117 \\
91 \\
95 \\
111 \\
92 \\
130 \\
109 \\
206\end{array}$ & $\begin{array}{l}123 \\
116 \\
155 \\
171 \\
177 \\
219 \\
146 \\
201 \\
216 \\
284\end{array}$ & $\begin{array}{r}13600 \\
8562 \\
18313 \\
15495 \\
16683 \\
24229 \\
13436 \\
26031 \\
23796 \\
19501\end{array}$ & $\begin{array}{r}103 \\
69 \\
128 \\
97 \\
92 \\
111 \\
103 \\
130 \\
110 \\
109\end{array}$ & $\begin{array}{l}127 \\
127 \\
169 \\
161 \\
165 \\
215 \\
143 \\
193 \\
196 \\
170\end{array}$ & $\begin{array}{r}13087 \\
8865 \\
21649 \\
15609 \\
15207 \\
23814 \\
14793 \\
25019 \\
21723 \\
17970\end{array}$ & $\begin{array}{r}105 \\
67 \\
114 \\
89 \\
84 \\
112 \\
94 \\
133 \\
104 \\
103\end{array}$ & $\begin{array}{l}129 \\
130 \\
158 \\
178 \\
165 \\
220 \\
145 \\
195 \\
200 \\
190\end{array}$ & $\begin{array}{r}13229 \\
8850 \\
17878 \\
15620 \\
13860 \\
24530 \\
13625 \\
25935 \\
20700 \\
19570\end{array}$ \\
\hline $\begin{array}{l}\text { Mean } \\
\text { SD }\end{array}$ & $\begin{array}{r}104 \\
21\end{array}$ & $\begin{array}{r}167 \\
34\end{array}$ & $\begin{array}{r}17764 \\
6470\end{array}$ & $\begin{array}{r}104 \\
16\end{array}$ & $\begin{array}{r}171 \\
36\end{array}$ & $\begin{array}{r}17965 \\
5543\end{array}$ & $\begin{array}{r}105 \\
18\end{array}$ & $\begin{array}{r}167 \\
29\end{array}$ & $\begin{array}{r}17774 \\
5176\end{array}$ & $\begin{array}{r}100 \\
18\end{array}$ & $\begin{array}{r}171 \\
31\end{array}$ & $\begin{array}{r}17350 \\
5428\end{array}$ \\
\hline
\end{tabular}

See table 2 for abbreviations.

Table 4 Mean time to angina ( $\mathrm{min}$ ), mean recovery time ( $\mathrm{min}$ ), and reason for interrupting the test

\begin{tabular}{|c|c|c|c|c|c|c|c|c|c|c|c|c|}
\hline \multirow[b]{3}{*}{ Case No } & \multirow{2}{*}{\multicolumn{3}{|c|}{ Run in }} & \multicolumn{6}{|c|}{ Treatment period } & \multirow{2}{*}{\multicolumn{3}{|c|}{ Post-treatment }} \\
\hline & & & & \multicolumn{3}{|c|}{ Without ESES } & \multicolumn{3}{|c|}{ With ESES } & & & \\
\hline & $\begin{array}{l}\text { Time to } \\
\text { angina }\end{array}$ & $\begin{array}{l}\text { Recovery } \\
\text { time }\end{array}$ & $\begin{array}{l}\text { Reason } \\
\text { to stop }\end{array}$ & $\begin{array}{l}\text { Time to } \\
\text { angina }\end{array}$ & $\begin{array}{l}\text { Recovery } \\
\text { time }\end{array}$ & $\begin{array}{l}\text { Reason } \\
\text { to stop }\end{array}$ & $\begin{array}{l}\text { Time to } \\
\text { angina }\end{array}$ & $\begin{array}{l}\text { Recovery } \\
\text { time }\end{array}$ & $\begin{array}{l}\text { Reason } \\
\text { to stop }\end{array}$ & $\begin{array}{l}\text { Time to } \\
\text { angina }\end{array}$ & $\begin{array}{l}\text { Recovery } \\
\text { time }\end{array}$ & $\begin{array}{l}\text { Reason } \\
\text { to stop }\end{array}$ \\
\hline $\begin{array}{l}1 \\
2\end{array}$ & $\begin{array}{l}2 \\
0 \cdot 7\end{array}$ & $\begin{array}{r}15 \cdot 5 \\
7 \cdot 7\end{array}$ & $\begin{array}{l}\text { Angina } \\
\text { Angina, } \\
\text { dyspnoea }\end{array}$ & $a^{1}$ & $\begin{array}{l}12 \\
7 \cdot 3\end{array}$ & $\begin{array}{l}\text { Angina } \\
\text { Angina, } \\
\text { dyspnoea }\end{array}$ & $\begin{array}{l}2 \cdot 6 \\
7\end{array}$ & $\begin{array}{l}9 \\
1.5\end{array}$ & $\begin{array}{l}\text { Dyspnoea } \\
\text { Dyspnoea }\end{array}$ & $\begin{array}{l}2.5 \\
1.0\end{array}$ & $\begin{array}{r}13 \\
7\end{array}$ & $\begin{array}{l}\text { Angina } \\
\text { Angina, } \\
\text { dyspnoea }\end{array}$ \\
\hline 3 & 1 & $1 \cdot 3$ & $\begin{array}{l}\text { Angina, } \\
\text { dyspnoea }\end{array}$ & $a^{3 \cdot 8}$ & 1 & $\begin{array}{l}\text { Angina, } \\
\text { dyspnoea }\end{array}$ & $a^{6 \cdot 6}$ & $0 \cdot 3$ & Dyspnoea & $4 \cdot 5$ & 0.5 & $\begin{array}{l}\text { Angina, } \\
\text { dyspnoea }\end{array}$ \\
\hline 4 & 1 & $9 \cdot 8$ & $\begin{array}{l}\text { Angina, } \\
\text { dyspnoea }\end{array}$ & 2.5 & 5 & $\begin{array}{l}\text { Angina, } \\
\text { dyspnoea }\end{array}$ & $a^{7}$ & 1 & Dyspnoea & 4 & $5 \cdot 5$ & $\begin{array}{l}\text { Dyspnoea, } \\
\text { angina }\end{array}$ \\
\hline $\begin{array}{l}5 \\
6 \\
7\end{array}$ & $\begin{array}{l}3 \cdot 3 \\
2 \\
3 \cdot 3\end{array}$ & $\begin{array}{l}1 \\
4 \cdot 7 \\
3 \cdot 3\end{array}$ & $\begin{array}{l}\text { Dyspnoea } \\
\text { Angina } \\
\text { Angina }\end{array}$ & $\begin{array}{l}5 \\
3 \cdot 2 \\
3 \cdot 0\end{array}$ & $\begin{array}{l}1 \\
5 \\
3 \cdot 0\end{array}$ & $\begin{array}{l}\text { Dyspnoea } \\
\text { Angina } \\
\text { Angina, } \\
\text { dyspnoea }\end{array}$ & $\begin{array}{l}7 \cdot 3 \\
8 \cdot 8 \\
5 \cdot 5 \\
a^{2}\end{array}$ & $\begin{array}{l}0 \\
0 \\
2 \cdot 8\end{array}$ & $\begin{array}{l}\text { Dyspnoea } \\
\text { Dyspnoea } \\
\text { Dyspnoea }\end{array}$ & $\begin{array}{l}6 \\
3 \\
3 \cdot 0\end{array}$ & $\begin{array}{l}1 \\
5 \\
3.5\end{array}$ & $\begin{array}{l}\text { Dyspnoea } \\
\text { Angina } \\
\text { Angina }\end{array}$ \\
\hline 8 & $1 \cdot 7$ & $3 \cdot 7$ & Angina & 1.8 & $3 \cdot 0$ & $\begin{array}{l}\text { Angina, } \\
\text { dyspnoea }\end{array}$ & 8 & 0 & Dyspnoea & $2 \cdot 0$ & $2 \cdot 5$ & $\begin{array}{l}\text { Angina, } \\
\text { dyspnoea }\end{array}$ \\
\hline $\begin{array}{r}9 \\
10\end{array}$ & $\begin{array}{l}2 \\
1 \cdot 0\end{array}$ & $\begin{array}{l}2 \cdot 3 \\
3 \cdot 0\end{array}$ & $\begin{array}{l}\text { Angina } \\
\text { Angina }\end{array}$ & $\begin{array}{l}2 \cdot 3 \\
1 \cdot 3\end{array}$ & $\begin{array}{l}3 \\
3 \cdot 3\end{array}$ & $\begin{array}{l}\text { Angina } \\
\text { Angina }\end{array}$ & $\begin{array}{l}3 \cdot 8 \\
3\end{array}$ & $\begin{array}{l}1 \cdot 5 \\
1 \cdot 3\end{array}$ & $\begin{array}{l}\text { Dyspnoea } \\
\text { Dyspnoea }\end{array}$ & $\begin{array}{l}2 \\
2 \cdot 0\end{array}$ & $\begin{array}{l}3.5 \\
3.5\end{array}$ & $\begin{array}{l}\text { Angina } \\
\text { Angina }\end{array}$ \\
\hline $\begin{array}{l}\text { Mean } \\
\text { SD }\end{array}$ & $\begin{array}{l}1.8 \\
0.9\end{array}$ & $\begin{array}{l}5.2 \\
4.5\end{array}$ & & $\begin{array}{l}2.4 \\
1.4\end{array}$ & $\begin{array}{l}4 \cdot 4 \\
3 \cdot 3\end{array}$ & & $\begin{array}{l}6 \cdot 0^{\star} \\
2 \cdot 2\end{array}$ & $\begin{array}{l}1 \cdot 7^{\star} \\
2 \cdot 7\end{array}$ & & $\begin{array}{l}3.0 \dagger \\
1.5\end{array}$ & $\begin{array}{l}4.5 \\
3.6\end{array}$ & \\
\hline
\end{tabular}

${ }^{\star} p<0.01$ for comparison of values with epidural spinal electrical stimulation and without epidural spinal electrical stimulation;

tp $<0.05$ for comparison of run-in and post-treatment values.

Table 5 Mean exercise tolerance (expressed in W. min)

\begin{tabular}{lllll}
\hline & & \multicolumn{2}{l}{ Treatment period } & \\
\cline { 3 - 4 } Case No & Run-in & $\begin{array}{l}\text { Without } \\
\text { ESES }\end{array}$ & $\begin{array}{l}\text { With } \\
\text { ESES }\end{array}$ & $\begin{array}{l}\text { Post- } \\
\text { treatment }\end{array}$ \\
\hline 1 & 200 & 218 & 255 & 255 \\
2 & 295 & 319 & 650 & 393 \\
3 & 523 & 593 & 713 & 680 \\
4 & 423 & 386 & 460 & 385 \\
5 & 362 & 362 & 412 & 385 \\
6 & 362 & 385 & 520 & 385 \\
7 & 523 & 516 & 590 & 505 \\
8 & 967 & 830 & 1083 & 910 \\
9 & 523 & 598 & 780 & 620 \\
10 & 303 & 330 & 356 & 330 \\
Mean & 448 & 453 & $581 \star$ & 483 \\
SD & 213 & 180 & 240 & 199 \\
\hline
\end{tabular}

${ }^{\star} p<0.01$ for comparison of values with epidural spinal electrical stimulation (ESES) and without epidural spinal electrical stimulation time to angina and a decrease in recovery time $(p<0.01$ for both, table 4).

The reasons for stopping the exercise were different during epidural spinal electrical stimulation when nine patients stopped because of dyspnoea and one patient stopped because of a combination of angina and dyspnoea.

\section{Discussion}

The results of the study accord with the short term effects of transcutaneous electrical nerve stimulation on angina pectoris. ${ }^{1}$ Thus epidural spinal electrical stimulation reduced chest pain, increased working capacity, reduced ST segment depression, increased time to angina, and reduced the recovery time. The 
Table 6 Mean ST segment depression ( $\mathrm{mm}$ ) at highest comparable workload and at maximal workload

\begin{tabular}{|c|c|c|c|c|c|c|c|c|}
\hline \multirow[b]{3}{*}{ Case No } & \multirow{2}{*}{\multicolumn{2}{|c|}{ Run in }} & \multicolumn{4}{|c|}{ Treatment period } & & \\
\hline & & & \multicolumn{2}{|c|}{ Without ESES } & \multicolumn{2}{|l|}{ With ESES } & \multicolumn{2}{|c|}{ Post-treatment } \\
\hline & $\begin{array}{l}\text { Comparable } \\
\text { workload }\end{array}$ & $\begin{array}{l}\text { Maximal } \\
\text { workload }\end{array}$ & $\begin{array}{l}\text { Comparable } \\
\text { workload }\end{array}$ & $\begin{array}{l}\text { Maximal } \\
\text { workload }\end{array}$ & $\begin{array}{l}\text { Comparable } \\
\text { workload }\end{array}$ & $\begin{array}{l}\text { Maximal } \\
\text { workload }\end{array}$ & $\begin{array}{l}\text { Comparable } \\
\text { workload }\end{array}$ & $\begin{array}{l}\text { Maximal } \\
\text { workload }\end{array}$ \\
\hline $\begin{array}{r}1 \\
2 \\
3 \\
4 \\
5 \\
6 \\
7 \\
8 \\
9 \\
10\end{array}$ & $\begin{array}{l}-0.6 \\
-0.1 \\
-2.0 \\
-2.4 \\
-0.7 \\
-3.8 \\
-2.0 \\
-2.3 \\
-2.7 \\
-2.6\end{array}$ & $\begin{array}{l}-0.6 \\
-0.1 \\
-1.9 \\
-2.7 \\
-0.9 \\
-3.8 \\
-2.1 \\
-3.1 \\
-3.1 \\
-2.6\end{array}$ & $\begin{array}{l}-0.7 \\
-0.1 \\
-1.8 \\
-3.0 \\
-0.2 \\
-3.4 \\
-1.8 \\
-2.4 \\
-3.1 \\
-2.6\end{array}$ & $\begin{array}{l}-0.7 \\
-0.1 \\
-1.9 \\
-3.3 \\
-0.2 \\
-3.5 \\
-2.1 \\
-2.6 \\
-3.6 \\
-2.6\end{array}$ & $\begin{array}{l}-0.7 \\
-0.1 \\
-1.0 \\
-2.2 \\
+0.3 \\
-2.5 \\
-1.4 \\
-1.8 \\
-1.8 \\
-1.8\end{array}$ & $\begin{array}{l}-0.7 \\
-0.1 \\
-1.8 \\
-2.7 \\
+0.2 \\
-3.0 \\
-1.8 \\
-3.1 \\
-3.2 \\
-1.8\end{array}$ & $\begin{array}{l}-0.7 \\
-0.2 \\
-1.9 \\
-2.6 \\
-0.1 \\
-4.0 \\
-2.0 \\
-2.8 \\
-2.6 \\
-2.7\end{array}$ & $\begin{array}{l}-0.7 \\
-0.2 \\
-2.3 \\
-2.6 \\
-0.1 \\
-4.3 \\
-2.3 \\
-3.1 \\
-3.6 \\
-2.7\end{array}$ \\
\hline $\begin{array}{l}\text { Mean } \\
\text { SD }\end{array}$ & $\begin{array}{r}-1.9 \\
1.1\end{array}$ & $\begin{array}{r}-2 \cdot 1 \\
1 \cdot 2\end{array}$ & $\begin{array}{r}-1.9 \\
1.2\end{array}$ & $\begin{array}{r}-2 \cdot 1 \\
1 \cdot 3\end{array}$ & $\begin{array}{c}-1 \cdot 3^{\star} \\
0.9\end{array}$ & $\begin{array}{r}-1.8 \\
1.3\end{array}$ & $\begin{array}{r}-2 \cdot 0 \\
1 \cdot 3\end{array}$ & $\begin{array}{r}-2 \cdot 2 \\
1 \cdot 4\end{array}$ \\
\hline
\end{tabular}

${ }^{\star} p<0.01$ for comparison of values with epidural spinal electrical stimulation (ESES) and without epidural spinal electrical stimulation at comparable workload.

patients remained on optimal antianginal treatment during the study. These effects are additional to those produced by conventional medical treatment of angina. In a previous study, the pain relieving effects of transcutaneous electrical nerve stimulation were investigated in patients with severe angina pectoris in pacing induced angina. ${ }^{4}$ The treatment had beneficial effects; it increased tolerance to pacing, improved lactate metabolism, and produced less ST segment depression.

The symptoms of angina pectoris are subject to various placebo influences and there is reason to believe that surgical procedures are especially likely to produce such effects, ${ }^{56}$ It is not possible to design a blind study of epidural spinal electrical stimulation since there is no acceptable placebo equivalent to the sensation of stimulation. Placebo effects must therefore be expected in this study.

"Soft" indices, such as time to angina, recovery time, and working capacity, are especially subject to the influence of placebo effects while "hard" data like the rate-pressure product and ST segment depression are probably less influenced by such effects. Because these variables were altered by electrical stimulation it seems reasonable to assume that physiological mechanisms other than the placebo effect are of importance in this study.

Previous studies have demonstrated that changes in the rate-pressure product are good predictors of myocardial oxygen consumption in patients with angina pectoris. ${ }^{7}$ At maximal comparable workload, the rate-pressure product did not differ between the patients treated with electrical stimulation and controls. Thus the effects of epidural spinal electrical stimulation on exercise induced angina pectoris seem not to be correlated to any changes in myocardial oxygen demand.

We believe that transcutaneous electrical nerve stimulation and epidural spinal electrical stimulation reduce some aspects of sympathetic activity. This explanation of their beneficial effects on angina pectoris is supported by the fact that treatment with transcutaneous electrical nerve stimulation reduced arterial concentrations of noradrenaline and adrenaline during atrial pacing. ${ }^{8}$ In two patients there was also an increase of dynorphin during transcutaneous electrical nerve stimulation suggesting that the endogenous opoid systems were affected.

In conclusion, the results of the study indicate that the antianginal effect of epidural spinal electrical stimulation is associated with decreased myocardial ischaemia, as shown by the reduction of ST segment depression. The effect seems to be additional to that of pharmacological treatment. The treatment was especially suitable for patients who had to withdraw from treatment with transcutaneous electrical nerve stimulation because of skin irritation and/or because the stimulation restricted their normally high physical activity.

\section{References}

1 Mannheimer C, Carlsson CA, Ericson K, Vedin A, Wilhelmsson C. Transcutaneous electrical nerve stimulation in severe angina pectoris. Eur Heart $J$ 1982;3:297-302.

2 Augustinsson LE, Carlsson CA, Holm J, Jivegård L. Epidural electrical stimulation in severe limb ischemia. Pain relief, increased blood flow, and a possible limb-saving effect. Ann Surg 1985;202:104-10. 
3 Bradley JM. Distribution-free statistical tests. London: Prentice-Hall, 1968.

4 Mannheimer C, Carlsson CA, Emanuelsson H, Vedin $A$, Waagstein $F$, Wilhelmsson $C$. The effects of transcutaneous electrical nerve stimulation in patients with severe angina pectoris. Circulation 1985;71: 308-16.

5 Dimond EG, Kittle CF, Crockett JE. Comparison of internal mammary artery ligation and sham operation for angina pectoris. Am J Cardiol 1960;5:483-6.

6 Benson H, McCallie DP Jr. Angina pectoris and the placebo effect. $N$ Engl J Med 1979;300:1424-9.

7 Nelson RR, Jorgensen CR, Wang Y. The rate-pressure product as an index of myocardial oxygen consumption during exercise in patients with angina pectoris. Circulation 1978;57:549-56.

8 Mannheimer C, Emanuelsson H, Waagstein F, Vedin $A$, Wilhelmsson $C$. The effect of transcutaneous electrical nerve stimulation on catecholamine metabolism during pacing-induced angina pectoris. In: $\mathrm{X}$ World Congress of Cardiology, Washington, no 561, 1986. Am Heart $J$ (in press). 